\title{
The Effectiveness of Village Fund Cash Block Grants (BLT) for the Poor Society Affected by the Covid-19 in Nangapanda District Ende Regency
}

\author{
${ }^{1}$ Hyronimus Se \\ Management Study Program \\ Flores University \\ Ende, East Nusa Tenggara \\ Email: ironimusodja@gmail.com
}

\author{
${ }^{2}$ Lambertus Langga \\ Management Study Program \\ Flores University \\ Ende, East Nusa Tenggara \\ Email: langgalambertus@yahoo.com
}

\begin{abstract}
It has been almost a year that the world has experienced suffering because of the emergence of an infectious disease type, namely the coronavirus (Covid-19). The coronavirus outbreak does not only affect health but also socio-economic conditions. The economic impact of the coronavirus outbreak has caused a decline in domestic economic activity so that reduced society's welfare. Recipients of direct cash assistance from village funds are families who have lost their livelihoods or have been laid off, have not received assistance from the Family Hope Program (PKH), Non-Cash Food Assistance (BPNT), worker cards, and recipients of UMKM assistance. The role of the government with the Village Fund Cash Block Grants (BLT) program is expected to have a positive role in the form of moral obligations to help realize the welfare of all levels of society by ensuring a balance between private and public interests and in maintaining the wheels of the economy on the right track. The data in the field shows that the distribution of Village Fund Cash Block Grants (BLT) has not been effective because it is not on target and there is an impression of the proximity factor of village officials. This study uses a qualitative method. This study was conducted in 29 villages in Nangapanda District, Ende Regency. The findings of the researchers indicated that the effectiveness of the direct block grants program from village funds was very beneficial for the poor and the society strongly supported village funds to be given to the society in cash other than to infrastructure development.
\end{abstract}

Keywords: Covid-19, direct block grants, effectiveness, poverty

\section{INTRODUCTION}

Poverty seems to be a giant that frightens all parties. The government of Indonesia and countries in the world make poverty a strategic issue that must be resolved from people's lives. Humans generally do not want poverty to not occur in their lives, therefore humans must fight the poverty that is afflicting them. It has been almost a year that the world has suffered from the emergence of a type of infectious disease, namely the coronavirus disease, which is often referred to as Covid-19. The coronavirus outbreak does not only affect health but also socio-economic conditions. The economic impact of the coronavirus outbreak has caused a decline in domestic economic activity, thus reducing people's welfare.
Coronavirus is a type of infectious disease that causes illness ranging from mild to severe symptoms.

The government demands that the government must be present to ensure the needs of the community, especially those affected by the coronavirus. The village government is experiencing a polemic, namely the data collection of potential recipients of direct cash assistance for poor families affected by the coronavirus. The village government must make every effort so that the BLT will be distributed on target, on people, on time, on the process, and administration reports.

The impact of the coronavirus pandemic on the world of labor in Indonesia is seen from the perspective of workers, entrepreneurs, and independent businesses. From the worker's side, there was a wave of layoffs and decreased income as a result of disruption to business activities in most sectors. This condition affects the survival of workers and their families.

Nangapanda District is the largest district in Ende Regency, East Nusa Tenggara Province with 29 villages whose people work as farmers and fishermen. During the coronavirus pandemic, the turnover of agricultural products such as cocoa, cloves, candlenut, and copra decreased due to unstable commodity prices which tended to decline, and fish production, which was the main source of income for fishermen, decreased due to the low purchasing power of the community. With the conditions of the coronavirus pandemic, the government has budgeted direct cash assistance from village funds based on the level of allocation of the number of village funds received. Permendes No. 6 of 2020 describes the criteria for the poor who are prospective recipients of direct Cash Block Grants (BLT), those who have lost their livelihoods or jobs, have not been recorded as receiving the Family Hope Program (PKH), Non-Cash Food Assistance (BPNT), basic food cards, UMKM social assistance, and preemployment cards.

Based on observations and interviews with informants in the field regarding the effectiveness of Village Village Fund Cash Block Grants (BLT) for the poor affected by Covid-19, several questions can be used as a problem formulation in this study, including 1) Is the direct cash assistance provided right on target for the poor who are affected by the coronavirus ?, and 2) Is the data collection of direct cash transfers the mechanism established by the Central Statistics Agency? 
The objectives of this study are 1) To find out and analyze whether or not Village Fund Cash Block Grants (BLT) is effective or not targeted to the poor affected by the coronavirus, and 2) To find out and analyze the methods and mechanisms for receiving direct cash assistance from village funds in Nangapada District, Regency Ende.

\section{LITERATURE REVIEW}

\subsection{Village Government}

A village is a legal community unit that has territorial boundaries that are authorized to regulate and manage the interests of the local community based on the rights of origin, customs, and socio-culture of the local community as long as it is still alive and community development and the principles of the Unitary State of the Republic of Indonesia. Based on the provisions stipulated in Law no. 6 of 2014 concerning villages, villages are the policy of the Indonesian government in terms of village autonomy, namely 1) the village has the authority to allocate village finances, 2) the authority of the village government in improving the economy and welfare of the community, and 3 ) the village community participates in the development carried out in the village (Kushandajani and Alfirdaus, 2019).

\subsection{Effectiveness Concept}

According to Cord Schmelzle (2011), effectiveness is not an objective category but depends on the government's intention or policy. The effectiveness in question is how a government organization can make a positive contribution to the welfare of the community the expected goals.

Meanwhile, Gie (in Maun, 2020) effectiveness is a situation that contains an understanding of the occurrence of a desired affect or effect. If someone does action with a specific purpose will have the intended purpose, then that person is said to be effective. According to Ravinato (2014), defining effectiveness is how well the work is done, the extent to which people produce outputs as expected. That is if a job can be completed with the plan, both in time, cost, and quality, it can be said to be effective.

Gibson et.al (in Bungkaes, 2013) effectiveness is an assessment made of individual, group and organizational achievements. The closer their achievement is to the expected achievement (standard), the more effective they are.

\subsection{Direct Cash Transfer Program}

The BLT policy is listed in Presidential Decree (Kepres) No. 9 of 2020 concerning the mandate of the President of the Republic of Indonesia to the Financial and Development Supervisory Agency (BPKP) as a Steering and Implementing member in the Task Force for the Acceleration of Handling Coronavirus. BLT is given to the poor, people who have lost their livelihoods, and to people whose family members are chronically ill.

The BLT program carried out by the government was intended not to reduce poverty, but to reduce the impact of the current economic situation. The program being implemented is expected to achieve the goals and objectives of providing BLT and reduce the pros and cons in the community. BLT does not increase the feeling of laziness for the recipient but describes the spirit to be strong in facing situations (Muliadi, 2015).

In the context of economic recovery during the coronavirus pandemic, the government issued a new Village Fund Cash Block Grants (BLT), namely productive Presidential Social Assistance (Banpres) for micro, small and medium enterprises (UMKM) of Rp. 2.4 million. This BLT program is intended for those who do not have a bank loan and is valid for all sectors with terms and conditions that have been set.

The role of the government is related to the concept and program of Village Fund Cash Block Grants (BLT) that has been implemented, it is hoped that a positive role is in the form of a moral obligation to help realize the welfare of all levels of society by ensuring a balance between private and public interests and in keeping the economy on the right track.

\subsection{The Concept of Poverty during the Coronavirus Pandemic}

The concept of poverty according to Lister (in Kasri, 2016) explains that poverty is a complex phenomenon and its size is often the subject of debate in academic circles. The development of an effective poverty alleviation policy cannot be carried out effectively without clear concepts and objectives. The effort that is taken to be consistent is relevant in measuring poverty.

The concept of poverty explains that the general standard of living in societies varies according to cultural definitions. Someone is categorized as poor not because their standard of living is low, but because their standard of living is lower than that of other people. Therefore, a person's lifeline will change according to economic development.

Kartono (in Tapung, et.al, 2020) states that the impact of the spread of the coronavirus (Covid-19) can result in a decrease in the quality and socio-economic conditions. The socio-economic quality has decreased because the source of income from the harvest has become less. This situation adds to the number of poverty and underdevelopment rates which can trigger the acceleration of the spread of this coronavirus. The assumption is that poverty and underdevelopment predispose to the spread of various diseases, including infectious diseases.

According to Syarifi, et.al. (2020) reveals that the socioeconomic impact of the coronavirus pandemic on developing and developed countries is the long-standing structural inequality that has occurred in society. Coronavirus has attacked human life, especially the poor, whose lives are very dependent on uncertain daily income.

\section{RESEARCH METHODOLOGY}

This study uses a qualitative method where qualitative research is a scientific method that is often used to examine the condition of a natural object (natural) and the researcher becomes a key instrument and the results of the research emphasize the meaning of what is being studied, rather than generalizing the object of research. To explore data in this study related to the effectiveness of direct cash transfers, the 
researchers used primary data and secondary data. The data analysis technique used in this research is qualitative analysis, namely the process of searching for and systematically compiling the results of interviews, observation, and documentation by coordinating data and selecting which ones are important and which ones need to be studied in making conclusions so that they are easy to understand.

\section{RESULTS AND DISCUSSION}

\subsection{Geographical Conditions}

Nangapanda District is the largest sub-district in Ende Regency, East Nusa Tenggara Province with an area of 213.17 $\mathrm{Km}^{2}$, has an area above sea level of 213.17 miles, and a population of 22,162 in 2017. Geographically, the Nangapanda sub-district has a strategic location, namely north of the border with Maukaro District, south of the border with the Savu Sea, east of the border with Ende District, and west of the border with Nagekeo Regency.

\subsection{Village Potential}

The potential condition in Nangapanda Subdistrict has sufficient resource potential and a leading potential is plantation crops which include cacao, cloves, coconut, candlenut, vanilla, nutmeg, and coffee. The coastal community has the fishery sector as a source of livelihood so that most of the people are fishermen.

Table 4.1

Plantation Products in Nangapanda District Year 2017-2018

\begin{tabular}{|c|l|c|c|}
\hline No. & Types of Plants & $\begin{array}{c}2017 \\
\text { (Tons) }\end{array}$ & $\begin{array}{c}2018 \\
\text { (Tons) }\end{array}$ \\
\hline 1 & Coconut & 2.195 & 2.194 \\
\hline 2 & Cocoa & 819 & 819 \\
\hline 3 & Cloves & 32,30 & 38 \\
\hline 4 & Coffee & 2.195 & 92 \\
\hline 5 & Candlenut & 746 & 720 \\
\hline
\end{tabular}

Source: Nagapanda in Numbers, 2020

Based on the types of plantation products, coconut and cocoa are superior products and have the potential to be developed into processed products to improve the economy of the community. The plantation sector is a sector that supports people's lives, smooth transportation is very helpful in marketing commodity products so that people do not need to sell to middlemen.

\subsection{Distribution of Direct Cash Assistance (BLT)}

Village Fund Direct Cash Assistance is a program of the central government through the Ministry of Villages, Development of Disadvantaged Areas, and Transmigration. The amount of village funds allocated for Direct Cash Assistance is adjusted to the total amount of village funds received by each village. Disbursement of Village Fund Cash Block Grants (BLT) for Village Funds affected by a coronavirus (Covid-19) in Nangapanda District of Rp. 600,000 were received by the poor for the first phase from April to
June and was extended until December, but in the second stage, the funds received were Rp. 300,000. Recipients of direct village cash assistance are families who have lost their livelihoods or have been laid off, have not received assistance from the Family Hope Program (PKH), Non-Cash Food Assistance (BPNT), worker cards, and recipients of UMKM assistance facilitated by the Cooperative Office and Bank Rakyat Indonesia.

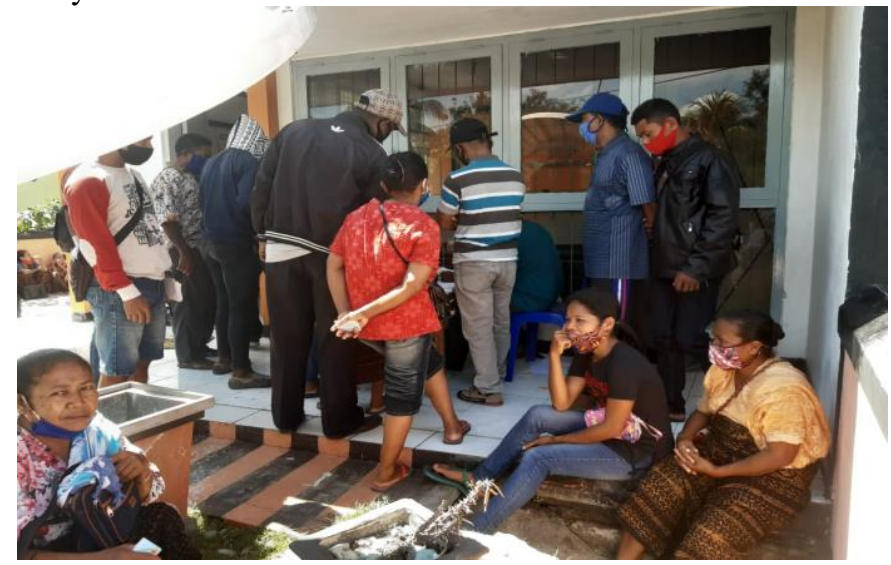

Figure 4.1. Withdrawal of Direct Cash Assistance in Nangapanda District

Table 4.2

Poor Families Receiving Village Fund BLT

\begin{tabular}{|c|c|c|c|}
\hline No. & Vilage-Sub District & Amount & BLT (Rp) \\
\hline 1. & Ondorea & 24 & $14,400,000,00$ \\
\hline 2. & Kelurahan Ondorea & 112 & $67,400,000,00$ \\
\hline 3. & Zozozea & 42 & $25,200,000,00$ \\
\hline 4. & Nggorea & 120 & $72,000,000,00$ \\
\hline 5. & Raporendu & 85 & $51,000,000,00$ \\
\hline 6. & Rapowawo & 71 & $42,600,000,00$ \\
\hline 7. & Bheramari & 24 & $14,400,000,00$ \\
\hline 8. & Kerirea & 59 & $35,400,000,00$ \\
\hline 9. & Tendarea & 62 & $37,200,000,00$ \\
\hline 10. & Watumite & 97 & $58,200,000,000$ \\
\hline 11. & Tendambepa & 2 & $1,200,000,00$ \\
\hline 12. & Ondorea Barat & 89 & $53,400,000,00$ \\
\hline 13. & Tiwerea & 71 & $42,600,000,00$ \\
\hline 14. & Ndorurea 1 & 34 & $20,200,000,00$ \\
\hline 15. & Ndeturea & 66 & $39,600,000,00$ \\
\hline 16. & Sanggarhorho & 56 & $33,600,000,00$ \\
\hline 17. & Penggajawa & 88 & $52,800,000,00$ \\
\hline 18. & Jegharangga & 0 & 0 \\
\hline 19. & Uzuzozo & 18 & $10,800,000,00$ \\
\hline 20. & Embuzozo & 49 & $29,400,000,00$ \\
\hline 21. & Anaraja & 54 & $32,400,000,00$ \\
\hline 22. & Kekandere & 27 & $16,200,000,00$ \\
\hline 23. & Tanazozo & 44 & $26,400,000,00$ \\
\hline 24. & Jemburea & 7 & $4,200,000,00$ \\
\hline 25. & Timbaria & 44 & $26,400,000,00$ \\
\hline 26. & Romarea & 20 & $12,000,000,00$ \\
\hline 27. & Mbobhenga & 23 & $13,800,000,00$ \\
\hline 28. & Malawaru & 12 & $7,200,000,00$ \\
\hline
\end{tabular}




\begin{tabular}{|c|c|c|c|}
\hline No. & Vilage-Sub District & Amount & BLT (Rp) \\
\hline 29. & TendaOndo & 44 & $26,400,000,00$ \\
\hline \multicolumn{2}{|c|}{ Nangapanda Subdistrict } & 1444 & $866,400,000,00$ \\
\hline
\end{tabular}

Source: Processed by researchers, 2020

\subsection{Research Results}

\subsubsection{Informant Descriptions}

In this research, researchers interviewed informants from several sub-district and village level officials in direct assistance programs and cash communities related to the effectiveness of direct Village fund cash assistance for poor communities affected by coronavirus disease (Covid-19) in Nangapanda District.

Table 4.3

Informant Description

\begin{tabular}{|c|l|c|}
\hline No. & \multicolumn{1}{|c|}{ Informant } & Total \\
\hline 1. & District Secretary & 1 \\
\hline 2. & Postal Clerk & 1 \\
\hline 3. & Village Head & 3 \\
\hline 4. & Village Officials & 5 \\
\hline 5. & Head of RT & 2 \\
\hline 6. & Chairman of RW & 2 \\
\hline 7. & Recipients of Assistance & 7 \\
\hline 8. & Society & 5 \\
\hline \multicolumn{2}{|c|}{ Total } & 26 \\
\hline
\end{tabular}

Source: Processed by researchers, 2020

\subsubsection{Punctuality of Time}

Timeliness in implementing an activity or program is an indicator to assess effectiveness in achieving goals. Timeliness in distributing Village Fund Cash Block Grants (BLT) is very necessary because time is a determining factor or measure so that the distribution of funds is the predetermined mechanisms and flow.

The spread of the coronavirus (Covid-19) which is endemic to the world has had an impact on the social and economic life of the people of Nangapanda District, Ende Regency, East Nusa Tenggara Province. Village fund budgets for infrastructure development in villages have been trimmed into direct cash assistance for village funds as social protection. The distribution of direct cash assistance from village funds to the people of Nangapanda Subdistrict is the mechanism which means that the distribution is fair, orderly and refers to data from the village government as well as targets that are truly feasible and entitled to receive direct cash assistance.

The data collection mechanism for poor families of potential recipients of direct cash assistance from funds is regulated as follows:

1. Village officials prepare village data concerning population data based on age, health, and education level.

2. The sub-district head coordinates with the village head to form a team and a letter of assignment to the officer or RT to collect data on poor families who are potential recipients of direct village cash assistance.

3. The head of the RT together with the officers will collect data using the data collection form in attachment two.
4. The clarification process is carried out by referring to the terms and conditions of recipients of village fund cash transfers:

- Poor families who are registered receive PKH, BPNT, assistance for UMKM actors, pre-employment assistance are excluded from the list of potential recipients of village fund direct cash assistance.

- Identifying poor families who are prone to illness is prioritized for receiving direct cash assistance from village funds.

- Conducting data fermentation of the population who receive direct cash assistance based on population data at the Department of Population and Civil Registration of Ende district

5. Prioritizing poor families who are prone to illness, women, and elderly people to receive BLT from village funds.

6. The results of the fermentation carried out by the Head of the RT, the Head of the RW, and the officers are conveyed to the Village Head as the person in charge of the village fund cash direct social assistance program.

7. Every activity in the field, both in the process of data collection and verification, must pay attention to and follow health protocols.

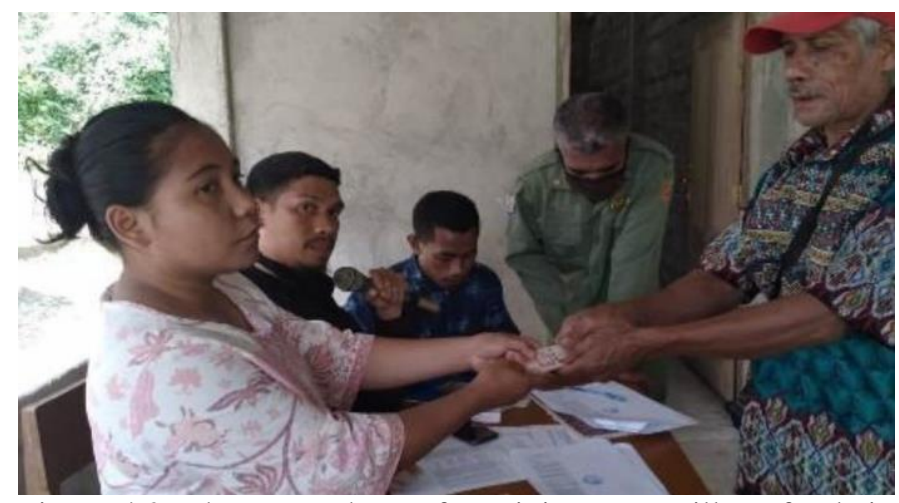

Figure 4.2. The atmosphere of receiving BLT-village funds in Jemburea village

Based on the information obtained by the researcher, the village fund direct cash assistance (BLT) has been running effectively and efficiently, but in the process of its implementation, it is controlled and controlled by the Regent through the cat or secretary of the cam. The researcher interviewed the informant, namely the Head of Kekandere Village, Mr. Maksimilianus Minu, regarding the process of distributing Village Fund Cash Block Grants (BLT) from the data collection process to the handover of money to the receiving community. that was impacted by Covid-19. The community is expected that the funds received can be used to buy necessities. Regarding the village funds given to the community for the initial stage of Rp. 600,000 and then extended to phase two amounting to Rp. 300,000. The distribution of village funds is existing data and applicable procedures".

The researcher also asked another source, namely $\mathrm{Mr}$. Marius, one of the village officials in Uzuzozo Village 
regarding the target of the village fund direct cash transfer program. In his explanation, "BLT village funds are intended for people who have never received other social assistance programs. Communities who have received PKH, BPNT, and basic food assistance programs are not included in the data of the community who receive direct cash assistance from village funds. This program helps the community in fulfilling their basic needs and can answer the wishes of people who previously did not receive assistance programs because so far some people have not accepted government policies which according to them are unfair and not on target in providing direct cash assistance".

The results of the research related to the timeliness of the distribution of BLT village funds showed that the distribution of funds the existing mechanisms and data flow so that the people who received BLT village funds were those whose names had been registered and had the right to receive so that there was no overlap with other beneficiaries.

\subsubsection{Direct Benefits}

Direct benefits can be defined as benefits that are enjoyed immediately because of the programs provided by the government or funds received. Providing direct cash assistance during the coronavirus pandemic by the government is an effort to minimize the impact of the Covid-19 pandemic. In addition to direct cash assistance, the government also provides basic food assistance, electricity bill relief, and credit restructuring for people who are making loans or people who have difficulty paying installments at banks or other financial institutions.

Providing direct cash assistance during the coronavirus pandemic by the government is an effort to minimize the impact of the Covid-19 pandemic. In addition to direct cash assistance, the government also provides basic food assistance, electricity bill relief, and credit restructuring for people who are making loans or people who have difficulty paying installments at banks or other financial institutions.

The researcher interviewed one of the residents who received direct cash assistance from village funds, namely $\mathrm{Mr}$. Alexander Rabu, a resident of Jemburea village regarding the direct benefits of the direct cash assistance program. "We are farmers because when we sell the produce, many people cannot afford it. With the BLT, village funds were very helpful so that we were able to buy basic daily necessities. This assistance is right for the community and the benefits are tremendous because of the conditions in Jemburea village since the pandemic, people find it difficult to get income. I hope that this assistance will continue and we are very supportive of Jokowi's government and if Jokowi is allowed to run again for a third term, I guarantee that the residents of Jemburea Village will 100 percent vote for Jokowi as president",

The researcher also interviewed a resident of Kekandere Village, Mrs. Fransiska, regarding the BLT. She said that "I am very grateful for the government assistance program because, during the pandemic, the community was very difficult to get money. With this grant, we can buy the things we need. The BLT that was given was right for those of us who needed it and was appropriate because almost all residents received program funding from the government".

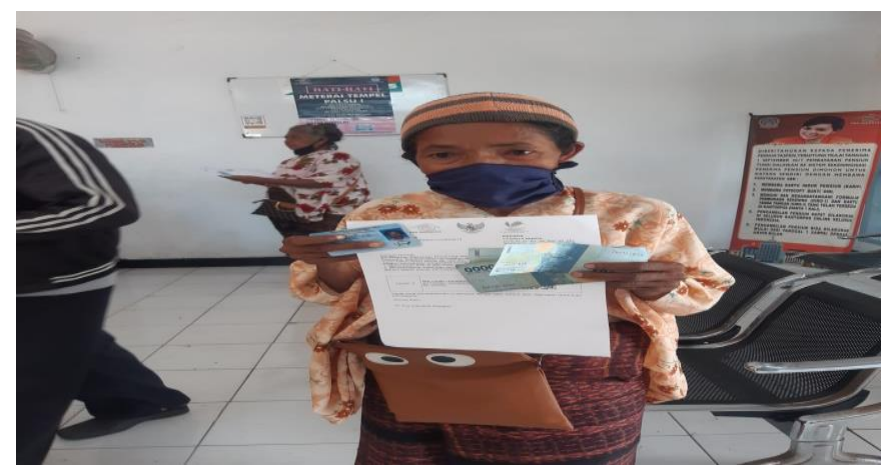

Figure 4.3. People who are currently receiving BLT

The results of research on the benefits of direct cash assistance provided by the government to the poor show that people are satisfied because the funds received can help the community in meeting their special daily basic needs during the coronavirus pandemic.

4.2.4 Target Accuracy

The process of distributing BLT village funds needs to be coordinated, starting from the central government to the village government. The role of the central government is in monitoring and supervising the implementation process of BLT village funds, thus local governments, in this case, both the provincial and district/city governments, can determine the number of social assistance targets that have not been met by BLT in village funds because the government has various social assistance programs.

The district government through related agencies coordinates with the government at the sub-district level to quickly collect data and validate proposed poor families so that the implementation of the Village Fund BLT program can be carried out effectively, efficiently, and transparently.

In the process of implementing the Village Fund Cash Block Grants BLT program that was provided during the coronavirus pandemic, the researcher with a community leader, Mr. Markus Meka, regarding the accuracy of targeting in the distribution of BLT village funds, he said that: "If I look at what the village government is doing the BLT provided For the poor, it was the procedure and right on target because on average BLT recipients were people with very minimal income. However, not receiving assistance so far, maybe the village government has prioritized those who need it. I hope that in the future we are among those affected by the coronavirus, so the government should be obliged to provide social assistance funds without exception".

The results showed that the distribution of direct cash assistance to village funds was the mechanism, but not accepted the government policy because it was considered that in the data collection process, prospective Village Fund Cash Block Grants BLT recipients were still impressed because of the proximity to village officials. However, as a whole, the community fully supports the government's program of assistance because it is very helpful in meeting their needs, especially during the pandemic era where all people feel. 


\section{CONCLUSION}

The government has implemented the right policy in dealing with the coronavirus pandemic by providing direct cash assistance from village funds. The distribution of BLT village funds to the poor affected by the coronavirus is the mechanism and the data registered as recipients of direct village fund cash assistance. Regarding the timeliness and direct benefits of BLT, village funds were appropriate and right on target so that the community was satisfied with the BLT village funds provided which were channeled in two stages, namely the first stage of Rp. 600,000.00 and will be extended to the second stage of Rp. 300.00 .

The government has worked the applicable mechanisms and provisions so that there is an impression in determining potential recipients of village fund BLT because the factor of closeness to village officials is not justified by the supervisory body at the district, provincial level, and even by the village government.

\section{REFERENCES}

Women's Empowerment(Kushandajani \& Alfirdaus, 2019)(Schmelzle, 2012)(Sharifi \& Khavarian-Garmsir, 2020)(Kasri, 2016)(International et al., 2001)(Pratama, 2015)(Savitri et al., 2018)(Azlina et al., 2017)(Tuwu, 2020)Azlina, N., Hasan, A., Desmiyawati, \& Muda, I. (2017). The effectiveness of village fund management (case study at villages in coastal areas in Riau). International Journal of Economic Research, 14(12), 325-336.

International, A., Agustin, J., Brunell, F., Donovan, J., Jung, K., Lloveras, F., Ritterbausch, R., Robinson, D., \& Valley, A. (2001). Effective Organizations T EAM E FFECTIVENESS IN M ULTINATIONAL O RGANIZATIONS: Center for Effective Organizations Abstract Incorporating team context into research and practice concerning team effectiveness in multinational organizations is an on-going $c$. 6(213).

Kasri, R. A. (2016). Effectiveness of Zakah Targeting in Alleviating Poverty in Indonesia. Al-Iqtishad: Journal of Islamic Economics, 8(2), 169 186. https://doi.org/10.15408/aiq.v8i2.3005

Kushandajani, \& Alfirdaus, L. K. (2019). Women's Empowerment in Village Governance Transformation in Indonesia: Between Hope and Criticism. International Journal of Rural Management, 15(1), 137157. https://doi.org/10.1177/0973005219836576

Pratama, Y. C. (2015). Analisis Faktor-Faktor Yang Mempengaruhi Kemiskinan Di Indonesia. Esensi, 4(2), 210-223. https://doi.org/10.15408/ess.v4i2.1966

Savitri, E., Gumanti, T. A., \& Diyanto, A. V. (2018). the Effectiveness of Allocated Village Funds Management. Journal of Applied Management, 16(4), 722-730.

Schmelzle, C. (2012). Evaluating Governance: Effectiveness and Legitimacy in Areas of Limited Statehood. SSRN Electronic Journal, November. https://doi.org/10.2139/ssrn.1986017

Sharifi, A., \& Khavarian-Garmsir, A. R. (2020). The COVID-19 pandemic: Impacts on cities and major lessons for urban planning, design, and management. Science of the Total Environment, 749, 1-3. https://doi.org/10.1016/j.scitotenv.2020.142391

Tuwu, D. (2020). Kebijakan Pemerintah Dalam Penanganan Pandemi Covid19. Journal Publicuho, 267. https://doi.org/10.35817/jpu.v3i2.12535 